\title{
EFFECT OF Telenomus remus NIXON (HYMENOPTERA: SCELIONIDAE) DENSITY ON CONTROL OF Spodoptera frugiperda (SMITH) (LEPIDOPTERA: NOCTUIDAE) EGG MASSES UPON RELEASE IN A MAIZE FIELD
}

\author{
MARIA DE LOURDES CORREAA FIGUEIREDO ${ }^{1}$, TEREZINHA MARIA CASTRO DELLA LUCIA², \\ IVAN CRUZ ${ }^{3}$ \\ ${ }^{1}$ Pesquisadora, bolsista CNPq, Embrapa Milho e Sorgo. Caixa Postal 151, CEP: 35701-970 Sete Lagoas, MG. E-mail: \\ lude@cnpms.embrapa.br (autor para correspondência) \\ ${ }^{2}$ Departamento de Biologia Animal, Universidade Federal de Viçosa. CEP: 36571-000 Viçosa, MG. \\ ${ }^{3}$ Pesquisador, Embrapa Milho e Sorgo. Caixa Postal 151, CEP: 35701-970 Sete Lagoas, MG.
}

Revista Brasileira de Milho e Sorgo, v.1, n.2, p.12-19, 2002

\begin{abstract}
The impact of releasing different densities (0,6,9 and 12 adult females $\left.\mathrm{m}^{-2}\right)$ of the egg parasitoid Telenomus remus Nixon on maize plants artificially infested with Spodoptera frugiperda (Smith) egg masses (one $\mathrm{m}^{-2}$ ) was evaluated. Egg masses were pinned in the midrib of the plant 36 days after planting. One egg mass contained approximately 65 eggs. The experimental design was in a randomized complete block design with five replications $\left(16 \mathrm{~m}^{2}\right.$ plots). There was a significant effect on percentage of parasitism egg masses. The highest parasitism values were verified in plots where 9 or 12 females of $T$. remus $\mathrm{m}^{-2}$ were released, respectively, 74 and $88.3 \%$. The relationship between percentage of parasitized egg masses and parasitoid densities was quadratic $\left(\mathrm{Y}=16.8+9.98 \mathrm{X}-0.35 \mathrm{X}^{2}, \mathrm{r}^{2}=0.99\right)$. The natural occurrence of Trichogramma spp. was relatively constant over the egg masses fixed on maize plants $(52.5 \%)$. However, the average T. remus parasitism on the eggs of a mass was much higher, representing $80.4 \%$ while the parasitism was only $21.3 \%$ in the case of Trichogramma. The presence of both parasitoids was responsible for up to $97.5 \%$ of parasitism, obtained from plots with a released density of 12 T. remus female $\mathrm{m}^{-2}$.
\end{abstract}

Key words: Insecta, fall armyworm, biological control, maize pest, parasitoid.

\section{EFEITO DA DENSIDADE DE Telenomus remus NIXON (HYMENOPTERA: SCELIONIDAE) NO CONTROLE DE OVOS DE Spodoptera frugiperda (LEPIDOPTERA: NOCTUIDAE) EM LIBERAÇÕES DE CAMPO, NA CULTURA DO MILHO}

RESUMO - Pesquisas foram realizadas para verificar o impacto da liberação de diferentes densidades $\left(0,6,9\right.$ e 12 fêmeas $\left.\mathrm{m}^{-2}\right)$ de Telenomus remus Nixon em plantas de milho infestadas artificialmente com massas de ovos (uma $\mathrm{m}^{-2}$ ) de Spodoptera frugiperda (J. E. Smith), fixadas na nervura principal da planta através de um grampo, 36 dias após o plantio. Cada massa de ovos continha cerca de 65 ovos. O delineamento experimental foi de blocos ao acaso, com cinco repetições (parcelas de $16 \mathrm{~m}^{2}$ ). Os valores mais altos de parasitismo foram verificados nas parcelas onde foram liberadas 9 ou 12 fêmeas de $T$. remus $\mathrm{m}^{-2}$, respectivamente, 74 e 88,3\%. A relação entre a percentagem de massas de ovos parasitadas e a densidade de parasitóides foi quadrática $\left(\mathrm{Y}=16,8+9,98 \mathrm{X}-0,35 \mathrm{X}^{2}, \mathrm{r}^{2}=0,99\right)$. A ocorrência natural de Trichogramma spp. sobre as massas de ovos de $S$. frugiperda foi relativamente constante $(52,5 \%)$, no entanto, o parasitismo médio de T. remus em cada massa de ovos foi 
maior, representando 80,4\%, enquanto que o parasitismo por Trichogramma representou $21,3 \%$. A presença de ambos os parasitóides foi responsável por um índice de parasitismo de até $97,5 \%$, obtido nas parcelas onde foram liberadas 12 fêmeas de T. remus $\mathrm{m}^{-2}$.

Palavras-chave: Insecta, lagarta-do-cartucho, controle biológico, praga de milho, parasitóide

The fall armyworm, Spodoptera frugiperda (Smith) (Lepidoptera: Noctuidae) is considered polyphagous and an important pest in maize in the Americas (Leiderman \& Sauer, 1953; Wiseman et al., 1966; Carvalho, 1970). Grain losses due to the damage of this pest can be up to $57.6 \%$ depending on plant development stage and maize type (Cruz \& Turpin, 1982, 1983, Cruz et al., 1996, 1999). The control of this insect pest on maize is based only on chemical pesticides, with increasing use each year in total acreage and number of applications; however without achieving the desirable control level (Notz, 1972; Cruz, 1995). Biological control using parasitoids or predators has been considered an ecological alternative as integrated pest management tactics (Cruz, 1995) because of the danger of chemical pesticide applications.

The use of natural enemies to suppress fall armyworm populations is recommended particularly for areas where chemicals are no more effective due to pest resistance or even due to environment concerns (Hanson \& Hilje, 1993; Leppla \& Williams, 1992).

Among several groups of insects, egg parasitoids such as Telenomus spp. (Hymenoptera: Scelionidae) have deserved great attention in different countries. This natural enemy has been considered to have great potential to control lepidopteran pests in crops such as cotton, rice, sugarcane and maize, as well as forest species and other crops of economic importance (Strand \& Vinson, 1982; Orr, 1988; Navarro, 1993; Polaszek \& Foerster, 1997). Telenomus remus Nixon is considered highly specific for species of the genus Spodoptera (Schwartz \& Gerling, 1974; Patel et al.,
1979; Dass \& Parshad, 1984; Kumar et al., 1984; Siabato, 1995), including $S$. frugiperda (Wojcik et al., 1976; Waddill \& Witcomb, 1982; Hernández et al., 1989; Cruz \& Figueiredo, 1994; Cruz, 1995). According to Kemp \& Simmons (1978) better levels of parasitism are obtained from areas with a greater number of egg hosts, although in some cases this response is not achieved (Yu et al., 1984; Yu \& Byers, 1994). Thus, it is important to know the amount of parasitoid to be released and the distribution points according to the host infestation level. Telenomus remus introduced in India in 1974 to control Spodoptera litura (Fabricius) in tobacco crop, was responsible for $60 \%$ of parasitized eggs from a release of 50,000 parasitoids $0.2 \mathrm{ha}^{-1} \mathrm{week}^{-1}$ (Patel et al., 1979). In Venezuela, Hernandez et al. (1989) observed parasitism levels varying from 60 to $80 \%$ in natural fall armyworm $S$. frugiperda egg masses infestation, after three consecutive weekly releases in maize. Similar levels of parasitism were observed in Colombia, after the release of 15,000,000 T. remus in 627 ha of rice, 507 of maize, 490 of cotton, 350 of soybean and 50 of sorghum (Siabato, 1995). The efficiency of T. remus alone or integrated with Baculovirus on the control of $S$. frugiperda population in maize field was reported by Figueiredo et al. (1999). The objective of this work was to evaluate the impact of releasing T. remus at different densities to control fall armyworm, $S$. frugiperda egg masses in maize.

\section{Material and Methods}

The research was conducted at Embrapa National Maize and Sorghum Research Center, Sete Lagoas, MG, latitude of $19^{\circ} 28^{\prime} 00^{\prime \prime}$ S. and longitude 
of $44^{\circ} 15^{\prime} 08^{\prime \prime}$ W., using the BR 205 maize hybrid, following local recommendations (Embrapa, 1982). The experimental design was a complete randomized block with four treatments (parasitoid density) and five replications. Each plot $\left(16 \mathrm{~m}^{2}\right)$ was composed of four maize rows, four meters long. The distance between plots was six meters. The center of each plot was marked with a pole where the parasitoids (24-hour old) were released in four densities: 0, 6, 9 and 12 adult females $\mathrm{m}^{-2}$. Daily natural egg mass surveys and removal to the laboratory were made inside the experimental unit before the artificial infestation and throughout the experimental period. The parasitoid was released 36 days after planting (DAP). The maize plants were at the 6-8-leaf stage $(59 \pm 1.5 \mathrm{~cm}$ tall). Just before the parasitoid release, the infestation with fall armyworm egg masses (24 hours old) was made (16 per plot, i. e. one $\mathrm{m}^{-2}$ ). The average number of egg/mass was around 65 . Egg masses were pinned in the mid-rib of the plant (36 days after planting) and one meter apart from each other. Forty-eight hours after infestation/release, the egg masses were removed to the laboratory. The removed egg masses were individually placed inside vials $(2.5 \times 10.0 \mathrm{~cm})$, under $25 \pm 2^{\circ} \mathrm{C}, \mathrm{RH} 70 \pm 10 \%$ with a 12 -hour photoperiod. Evaluations were based on the parasitism (\%) by T. remus and on the presence of other natural enemies. Analysis of variance was performed on the data and regression curves were calculated. Means were compared by Duncan's multiple range test $(\mathrm{P} \leq 0.05)$.

\section{Results and Discussion}

The total number of natural oviposition by $S$. frugiperda found in the experimental area was only eight. From those egg masses, only one was found to be parasitized by T. remus. This parasitized egg mass was found three days after the release of the parasitoid. No other egg parasitoid was found.

\section{Predation on egg masses from artificial infestation}

Doru luteipes (Scudder) (Dermaptera: Forficulidae) was the main predator found inside the experimental area. According to Reis et al. (1988) and Cruz \& Oliveira (1997) this predator has shown a great potential as a biological control agent against two key pests of maize, the fall armyworm, $S$. frugiperda and the corn earworm Helicoverpa zea (Boddie). Cruz \& Oliveira (1997) reported the results of a survey during six years in an area close to the present research. The predator occurred during all months of the year, with the greatest occurrence during the summer period (December to February). On average, $42.8 \%$ of the plants showed this insect, and in some cases reaching 95\%. In this experiment, predators were responsible for $6 \%$ of predation of the egg masses from the artificial infestation. Predation by this insect can reach up to $50 \%$ in maize ( $\mathrm{Yu} \&$ Byers, 1994) and 91 to $98 \%$ in cotton (Jones et al., 1977). Sá (1991) reported an inverse relationship between parasitism and predation of corn earworm $H$. zea eggs when parasitized by $T$. pretiosum. Losey \& Calvin (1991) also reported a significant effect of predation on eggs of Ostrinia nubilalis (Hubner) parasitized by T. pretiosum in sweet corn. According to Smith (1996) the level of predation should be considered when releasing parasitoids to guarantee success and low cost of the biological control program.

\section{Occurrence of T. remus on egg masses}

The parasitism verified in check treatments (without releasing parasitoid) was due to the dispersion of the insect, since they were not present in the area, as verified on samples evaluated on a previous date. This indicates that the distance between plots $(6 \mathrm{~m})$ was not enough to isolate them. The parasitism in the check plot was 16.3\% (Table 1), indicating the dispersion and search ability to survive 
TABLE 1. Parasitism of fall armyworm, Spodoptera frugiperda, after releasing Telenomus remus females at different densities, in maize field.

\begin{tabular}{cccc}
\hline $\begin{array}{c}\text { Number of females of } T . \\
\text { remus released } \mathbf{m}^{-2}\end{array}$ & $\begin{array}{c}\text { Egg masses parasitized by } \\
\text { T. remus }(\%)^{1}\end{array}$ & $\begin{array}{c}\text { Egg masses parasitized by } \\
\text { Trichogramma spp. (\%) }\end{array}$ & $\begin{array}{c}\text { Egg masses parasitized } \\
\text { by Telenomus and/or } \\
\text { Trichogramma }(\%))^{1}\end{array}$ \\
\hline 0 & $16.3 \pm 6.2 \mathrm{~B}$ & $46.7 \pm 5.8 \mathrm{~A}$ & $46.7 \pm 5.8 \mathrm{C}$ \\
6 & $67.4 \pm 3.4 \mathrm{~A}$ & $53.7 \pm 4.1 \mathrm{~A}$ & $82.6 \pm 4.6 \mathrm{~B}$ \\
9 & $74.4 \pm 4.2 \mathrm{~A}$ & $57.0 \pm 6.1 \mathrm{~A}$ & $91.7 \pm 2.7 \mathrm{AB}$ \\
12 & $88.3 \pm 4.1 \mathrm{~A}$ & $52.7 \pm 6.2 \mathrm{~A}$ & $97.5 \pm 2.5 \mathrm{~A}$ \\
\hline Mean & 61.6 & 52.5 & 79.6 \\
\hline $\mathrm{CV}(\%)$ & 16.7 & 7.4 & 5.5 \\
\hline
\end{tabular}

${ }^{1}$ Means within each column followed by the same letter are not significantly different $(\mathrm{P} \leq 0.05$; Duncan's multiple range test).

and establish in new areas. The percentage of fall armyworm egg masses parasitized by T. remus was not significantly different among released densities, with an average of $76.7 \%$ (Table 1 ). This average can be considered outstanding since values between 60 and $70 \%$ are common (Patel et al., 1979; Smith, 1996). The relationship between percentage of parasitized egg masses and parasitoid densities (Figure 1) was quadratic ( $\mathrm{Y}=16.8+9.98 \mathrm{X}-0.35$ $\left.\mathrm{X}^{2}, \mathrm{r}^{2}=0.99\right)$. When 12 females $\mathrm{m}^{-2}$ were used, parasitism was $88.3 \%$. However, the curve was ascendant indicating that greater parasitism could be expected with higher densities.

\section{Occurrence of T. remus and/or Trichogramma spp.}

The natural occurrence of Trichogramma spp. itself or together with $T$. remus was relatively constant over the egg masses fixed on maize plants. The average egg masses parasitized by Trichogramma spp. was $52.5 \%$ (Table 1). However, the most important point to consider here is that, altogether, the two species of parasitoids were responsible for up to $97.5 \%$ of parasitism, obtained from plots with a released density of 12 T. remus female $\mathrm{m}^{-2}$. This average parasitism was not significantly different from plots with nine females $\mathrm{m}^{-2}$ (91.7\% parasitism). The field mutual interference of these parasitoids can hinder the evaluation of the impact of each species alone. However, based on the results presented here, there seems to be a potential for using both parasitoids in biological control program of $S$. frugiperda on maize crop.

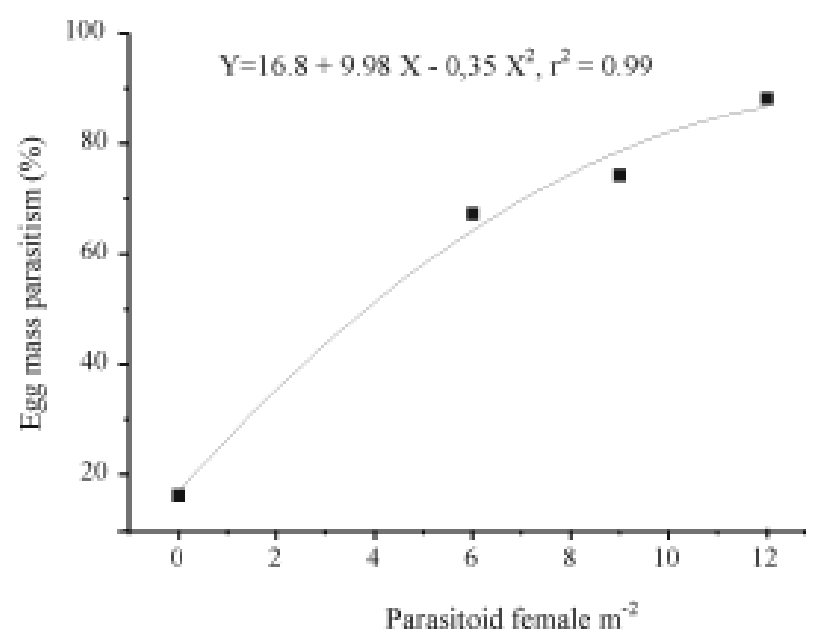

FIGURE 1. Relationship between fall armyworm (Spodoptera frugiperda) egg masses parasitism and densities of the parasitoid Telenomus remus. 
Considering that Trichogramma was already in the maize field, it seems that $T$. remus is more aggressive towards $S$. frugiperda egg masses, as pointed out by Hamada (1992) in relation to $S$. litura, where the natural egg mass parasitism was $2.9 \%$ for Trichogramma spp. and $16.1 \%$ for Telenomus sp. Besides, an average of only $21.3 \%$ of the egg in a mass was parasitized by Trichogramma, compared with $80.4 \%$ in the case of $T$. remus (Table 2 ).

TABLE 2. Parasitism (\%) of Telenomus remus and Trichogramma spp. in fall armyworm (Spodoptera frugiperda) egg masses after releasing T. remus, in maize field.

\begin{tabular}{ccc}
\hline $\begin{array}{c}\text { Number of } \\
\text { females of } \\
\text { T. remus } \\
\text { released m }\end{array}$ & $\begin{array}{c}\text { Parasitism of } T . \\
\text { remus per egg }^{-2} \\
\text { mass (\%) }\end{array}$ & $\begin{array}{c}\text { Parasitism of } \\
\text { Trichogramma } \\
\text { spp. per egg } \\
\text { mass (\%) }\end{array}$ \\
\hline 0 & $78.7 \pm 5.9 \mathrm{~A}$ & $20.2 \pm 1.3 \mathrm{~A}$ \\
6 & $75.9 \pm 4.7 \mathrm{~A}$ & $21.2 \pm 2.8 \mathrm{~A}$ \\
9 & $81.9 \pm 7.9 \mathrm{~A}$ & $22.3 \pm 5.0 \mathrm{~A}$ \\
12 & $84.9 \pm 5.0 \mathrm{~A}$ & $21.3 \pm 4.5 \mathrm{~A}$ \\
\hline Mean & 80.4 & 21.3 \\
\hline CV (\%) & 8.4 & 19.5 \\
\hline
\end{tabular}

${ }^{1}$ Means within each column followed by the same letter are not significantly different $(\mathrm{P} \leq 0.05$; Duncan's multiple range test).

Inundative releases require the number of parasitoids to be synchronized with the beginning of pest oviposition, and its density which is frequently difficult to determine in the field. Sometimes it can be greater than the parasitism potential of a natural enemy. For these reasons, the inoculative releases are more reasonable to improve the parasitoid performance over the pest. In this experiment the parasitoid was released only once. Probably releasing at different periods of time can enhance the parasitoid action. Further, studies are evidently necessary using a density of at least 12 female/egg masses as a starting point, but varying the fall armyworm egg mass density per area in maize fields. Also, in tactics of integrated pest management using biological control, the possible inter-specific competition or even the advantage of two or more natural enemies such as Trichogramma spp. and T. remus should be considered in achieving a better control of $S$. frugiperda in maize crop.

\section{Acknowledgements}

We are grateful to CAPES (Coordenação de Aperfeiçoamento de Pessoal de Nível Superior) for the scholarship and to the National Maize and Sorghum Research Center, for the financial support for this research and to Dr. Andrey Polaszek (International Institute of Entomology, London) for identifying the species Telenomus remus Nixon.

\section{References}

CARVALHO, R.P.L. Danos, flutuação da população, controle e comportamento de Spodoptera frugiperda (J.E.Smith, 1797) e susceptibilidade de diferentes genótipos de milho, em condições de campo. 1970. 170 f. Tese (Doutorado em Ciências) Universidade de São Paulo, Escola Superior de Agricultura Luiz de Queiroz, Piracicaba.

CRUZ, I.; TURPIN, F.T. Efeito da Spodoptera frugiperda em diferentes estágios de crescimento da cultura de milho. Pesquisa Agropecuária Brasileira, Brasília, v.17. p.355-359, 1982.

CRUZ, I.; TURPIN, F.T. Yield impact of larval infestation of the fall armyworm Spodoptera frugiperda (J.E. Smith) to mid-whorl growth stage of corn. Journal of Economic Entomology, College Park v.76. p.1052-1054. 1983.

CRUZ, I.; FIGUEIREDO, M.L.C. Estudos preliminares do parasitóide Telenomus sp. Nixon sobre ovos de Spodoptera frugiperda. Relatório Técnico 
Anual do Centro Nacional de Pesquisa de Milho e Sorgo 1992-1993, Sete Lagoas, v.6, p.104105, 1994.

CRUZ, I. A lagarta-do-cartucho na cultura do milho. Sete Lagoas: EMBRAPA - CNPMS, 1995. 45p. (EMBRAPA - CNPMS. Circular Técnica, 21).

CRUZ, I.; OLIVEIRA, L.J.; OLIVEIRA, A.C.; VASCONCELOS, C.A. Efeito do nível de saturação de alumínio em solo ácido sobre os danos de Spodoptera frugiperda (J.E. Smith) em milho. Anais da Sociedade Entomológica do Brasil, Jaboticabal, v. 25, p. 293-297, 1996.

CRUZ, I.; OLIVEIRA, A.C. Flutuação populacional do predador Doru luteipes (Scudder) em plantas de milho. Pesquisa Agropecuária Brasileira, Brasília, v.32, p.363-368, 1997.

CRUZ, I.; FIGUEIREDO, M.L.C.; OLIVEIRA, A.C.; VASCONCELOS, C.A. Damage of Spodoptera frugiperda (Smith) in different maize genotypes cultivated in soil under three levels of aluminium saturation. International Journal of Pest Management, London, v.45, p.293-296, 1999.

DASS, R.; PARSHAD, B. Rearing of important lepidopterous pests on known artificial diet and screening for preferred hosts of the parasite, Telenomus remus Nixon (Hymenoptera: Scelionidae). Journal of Entomological Research, New Delhi, v.8, p.89-92, 1984.

EMBRAPA. Centro Nacional de Pesquisa de Milho e Sorgo. Recomendações técnicas para o cultivo do milho. Sete Lagoas, 1982. 49p. (EMBRAPA - CNPMS. Circular Técnica, 4).

FIGUEIREDO, M.L.C.; CRUZ, I.; DELLA LUCIA, T.M.C. Controle integrado de Spodoptera frugiperda (Smith \& Abbott) utilizando-se o parasitóide Telenomus remus Nixon. Pesquisa
Agropecuária Brasileira, Brasília, v.34, p.19751982, 1999.

HAMADA, R. Egg parasitoids of common, Spodoptera litura (Fabricius). Applied Entomology and Zoology, Tokyo, v.36, p.258259, 1992.

HANSON, P.; HILJE, L. Control biologico de insectos. Turrialba: Centro Agronomico Tropical de Investigacion y Enseñanza, 1993. 40p. (Informe Técnico, 208).

HERNÁNDEZ, D.; FERRER, F.; LINARES, B. Introduccion de Telenomus remus Nixon (Hy.: Scelionidae) para controlar Spodoptera frugiperda (Lep.: Noctuidae) en Yaritagua-Venezuela. Agronomia Tropical, Maracay, v.39, p.199-205, 1989.

JONES, S.L.; MORRISON, R.K.; ABLES, J.R.; BULL, D.L. A new and improved technique for the field release of Trichogramma pretiosum. Southwestern Entomologist, College Station, v.2, p.210-215, 1977.

KEMP, W.P.; SIMMONS, G.A. The influence of stand factors on parasitism of spruce budworm eggs by Trichogramma minutum. Environmental Entomology, College Park, v.7, p.685-688, 1978.

KUMAR, D.A.; DIVAKAR, B.J.; PAWAR, A.D. Observation on the storage of life stages of Telenomus remus Nixon (Hymenoptera: Scelionidae) under low temperature. FAO Plant Protection Bulletin, Rome, v.36, p.13-14, 1984.

LEIDERMAN, L.; SAUER, H.F.G. A lagarta dos milharais Laphygma frugiperda (Abbot \& Smith, 1797). O Biológico, São Paulo, v.19, p.105-113, 1953.

LEPPLA, N.C.; WILLIAMS, D.W. Mass rearing beneficial insects and the renaissance of control. Pesquisa Agropecuária Brasileira, Brasília, v.27, p.231-238, 1992. 
LOSEY, J.E.; CALVIN, D.D. Parasitization efficiency of five species of Trichogramma (Hymenoptera: Trichogrammatidae) on european corn borer eggs. In: INTERNATIONAL SYMPOSIUM ON Trichogramma AND OTHER EGG PARASITES, 3. 1990, San Antonio, Texas Les colloques ... San Antonio: INRA, 1991. p.209212 .

NAVARRO, M.A. Produccion, uso y manejo de Trichogramma spp. (Hy.: Trichogrammatidae) como método de control biológico. In: CONGRESSO LATINOAMERICANO DE ENTOMOLOGIA, 5., CONGRESSO VENEZOLANO DE ENTOMOLOGIA, 13., 1993, Porlamar. Resumeres ... Caracas: Universidade Central, IV.B.S / Fundacion Polar, 1993. p.257-258.

NOTZ, P.A. Parasitismo de Diptera e Hymenoptera sobre larvas de Spodoptera frugiperda (Smith) (Lepidoptera: Noctuidae) recolectadas em maiz, Macaray, Venezuela. Revista de la Facultad de Agronomia, Maracay, v.6, p.5-16, 1972.

ORR, D.B. Scelionid wasps as biological control agents: a review. Florida Entomologist, Gainsville, v.71, p.506-528, 1988.

PATEL, R.C.; YADAV, D.N.; SARAMMA, P.U. Impact of mass releases of Chelonus heliopae Gupta and Telenomus remus Nixon against Spodoptera litura (Fabricius). Journal of Entomological Research, New Delhi, v.3, p.53-56, 1979.

POLASZEK, A.; FOERSTER, L.A. Telenomus cyamophylax, n.sp. (Hymenoptera: Scelionidae) attacking eggs of the velvetbean caterpillar, Anticarsia gemmatalis Hübner (Lepidoptera: Noctuidae). Anais da Sociedade Entomológica do Brasil, Jaboticabal, v.26, p.177-181. 1997.

REIS, L.L.; OLIVEIRA, L.J.; CRUZ, I. Biologia e potencial de Doru luteipes no controle de
Spodoptera frugiperda. Pesquisa Agropecuária Brasileira, Brasília, v.23, p.333-342. 1988.

SÁ, L.A.N. Bioecologia de Trichogramma pretiosum Riley, 1879, visando avaliar o potencial para controle de Spodoptera frugiperda (J.E. Smith, 1797) e Helicoverpa zea (Boddie, 1850) em milho. 1991. 170 f. Tese (Doutorado em Ciências) Universidade de São Paulo, Escola Superior de Agricultura Luiz de Queiroz, Piracicaba.

SCHWARTZ, A.; GERLING, D. Adult biology of Telenomus remus (Hymenoptera: Scelionidae) under laboratory conditions. Entomophaga, Paris, v.19, p.482-492, 1974.

SIABATO, J.A. Manejo biológico aplicado del complejo Spodoptera (Lep.: Noctuidae) con el parasito Telenomus remus Nixon (Hym.: Scelionidae). Resumenes. In 22 CONGRESO DE LA SOCIEDAD COLOMBIANA DE ENTOMOLOGÍA, 22., 1995, Santa Fé de Bogota. Resumenes ..., 1995. p.11.

SMITH, S.M. Biological control with Trichogramma: advances, successes, and potential of their use. Annual Review of Entomology, Polo Alto, v.41, p.375-406. 1996.

STRAND, M.R.; VINSON, S.B. Source and characterization of an egg recognition kairomone of Telenomus heliothidis, a parasitoid of Heliothis virescens. Physiological Entomology, Oxford, v.7, p. 83-90, 1982.

WADDILL, van H.; WHITCOMB, W.H. Release of Telenomus remus (Hym.: Scelionidae) against Spodoptera frugiperda (Lep.: Noctuidae) in Florida, U.S.A. Entomophaga, Paris, v.27, p.159-162, 1982.

WISEMAN, B.R.; PAINTER, R.H.; WASSON, C.E. Detecting corn seedling differences in the 
greenhouse by visual classification of damage by the fall armyworm. Journal of Economic Entomology, College Park, v.59, p.1211-1214, 1966.

WOJCIK, B.; WHITCOMB, W.H.; HABECK, D.H. Host range testing of Telenomus remus (Hymenoptera: Scelionidae). Florida Entomologist, Gainsville, v.59, p.195-198 1976.

YU, D.S.K.; LAING, J.E.; HAGLEY, E.A.C. Dispersal of Trichogramma spp. (Hy.:
Trichogrammatidae) in an apple orchard after inundative releases. Environmental Entomology, College Park, v.13, p.371-374, 1984.

YU, D.S.K.; BYERS, J.R. Inundative release of Trichogramma brassicae Bezdenko (Hy.: Trichogrammatidae) for control of European corn borer in sweet corn. Canadian Entomologist, Ottawa, v.126, p. 291-301, 1994. 